\title{
IMMUNE AND NEUROENDOCRINE ALTERATIONS IN LONG-DISTANCE RUNNING RACE
}

\author{
By \\ El-Shamra GS and Darwish FA \\ Department of Biological Science \& Sports Health \\ Faculty of Physical Education for Girls, Helwan University
}

\begin{abstract}
Introduction: Long-distance running race is a stressful event that can significantly affect virtually any of the physiologic systems of runners. More recently evidence has been mounting to support the long-distance running perception that athletes are susceptible to certain illness during intense training and major competition. Aim of Work: To focus on the immune function and neuroendocrine parameters response to prolonged (90 $\mathrm{min}$ ) and intensive endurance running. Materials and Methods: Blood samples were collected from 12 male children runners $(13.51 \pm 1.29$ years $) 0 \mathrm{~h}, 1$ hour, after the race. Complete blood count, secretion of cytokines in mitogen-activated cell culture and plasma, plasma concentration of $\beta$-endorphin, adrenocorticotropic hormone (ACTH), cortisol, and growth hormone (GH) were analyzed. Results: Significant increase in granulocyte and monocytes (MID-cell) count and lymphopenia were seen immediately after the race. Secretion of interleukin2 (IL-2) and interferon (IFN- $\gamma$ ) significantly declined at $0 \mathrm{~h}$ and $1 \mathrm{~h}$ after the running. Secretion of Tumor Necosis Factor (TNF- $\alpha$ ) declined at $0 \mathrm{~h} \&$ remained suppressed until 1hours. Suppression in the secretion of (IL-1 $\beta$ ) was observed at 1 hour. Activated secretion of (IL-6) decreased after 1hours. Peak concentrations of ACTH, cortisol, $\beta$-endorphin, and GH were registered after the race $(0 \& 1 \mathrm{~h})$. Conclusion: We co-ncluded that long-distance running race associated stress factors can alter physiologic balan-ce of cell-mediated versus humoral and antiinflammatory versus proinflammatory cytokin-es. Results suggest that hypothalamicpituitary-adrenocortical axis hormones played a sign-ificant role in the regulation of the observed changes. This information may be beneficial for development of new stress countermeasures to preserve wellness in subjects undergoing intensive physiological stress.
\end{abstract}

Key words: Long-distance running, Cytokines, Immunomodulation, Inflammation, Cell- mediated, Humoral. 


\section{Introduction}

A competitive long-distance running is a very stressful event and can significantly affect virtually any of the physiologic systems of runners. Dehydration, weight loss, gastrointestinal problems (bleeding), hypo or hyperthermia, collapse, muscle damage and microtrauma are often seen after a long-distance running race (Appell et al, 1992). More recently evidence has been mounting to support the long-held perception that athletes are susceptible to certain illness during intense training and major competition (Laurel, 1999). Epidemiological data suggest that endurance athletes are at increased risk for upper respiratory tract infection (URTI) during periods of heavy training and the 1 to 2 -wk period following race events. The macrophages and neutrophils of the innate immune system provide a first line of defense against many common microorganisms and are essential for the control of common bacterial infections (Baril et al., 1998, Nieman et al.,2002). Anumber of epidemiologic studies have shown increased risk of URTI in athletes up to 2 weeks after endurance races (Nieman et al.. 1990, Peters et al., 1997). In vitro and in vivo response of pro and antiinflammatory cytokines to marathon running has been studied intensively (Drenth et al., 1995, Ostrowski et al., 2000, Suzuki et al., 2003). However, there is limited and often contradictory information pertaining to cytokinepromoted cell-mediated (type-1) versus humoral (type-2) immune response to endurance running or exercise Weinstock et al. (1997), showed a significant decrease in mitogenactivated secretion of interleukin (IL-2) and interferon (IFN- $\gamma$ ) one hour after exhaustive competitive exercise (sprint triathlon). Similarly, a significant decrease of endotoxin-B induced IFN- $\gamma$ secretion was observed 30 minutes after exhaustive ergometer exercise (Baum et al., 1997). At the same time, no changes in the plasma concentration of IFN- $\gamma$, IL-1, IL-12, IFN- $\alpha$, and tumor necrosis factor $(\mathrm{T}-\mathrm{NF}-\alpha)$ were registered after the marathon in the study of (Suzuki et al., 1995). It was accompanied by a significant increase in concentration of IL-10, although concentrations of IL-4 and TGF- $\beta$ were unaffected by the race (Suzuki et al., 2000). 
There is growing evidence that, for several hours subsequent to heavy exertion, several components of both the innate (e.g., natural killer cell activity and neutrophil oxidative burst activity) and adaptive (e.g., $\mathrm{T}$ and $\mathrm{B}$ cell function) immune system exhibit suppressed function (Daynes \& Araneo., 1989). At the same time, plasma pro and anti-inflammatory cytokines are elevated, in particular interleukin-6 and interleukin-receptor antagonist. Various mechanisms explaining the altered immunity have been explored; including hormone induced trafficking of immune cells and the direct influence of stress hormones, prostaglandin-E2, cytokines, and other factors. High intensity exercise and prolonged exercise both increase cortisol levels (Viru A, Viru M., 2004).

Physiologic and psychological stress factors of exhaustive endurance exercise may affect the cell mediatedhumoral immune equilibrium through perturbations in the neuroendocrine system. One of the major events that occur during the neuroendocrine stress reaction to a marathon run is the activation of the hypothalamic-pituitary adrenocortical (HPA) axis (O'Connor et al., 1995, Banfi et al., 1996). Dramatic elevation of ACTH, endorphins, and cortisol is a classic representation of the HPA axis response to a prolonged bout of exercise (Scavo et al., 1991, Heitkamp et al., 1996). Cortisol is well known for its anti-inflammatory and immunosuppressive properties (Molijn et al., 1995, Bauer et al., 2000).

Aim of Work: This study was designed to investigate effects of LongDistance

Running associated stressors on cell mediated versus humoral and anti-inflammatory versus proinflammatory equilibrium as well as their correlations to neuroendocrine response. We measured secretion of cytokines, which support cell-mediated reactions or favor humoral immunity and are involved in inflammatory mechanisms. Additionally, we assessed plasma concentrations of hormones to investigate their involvement in the stress associated immune alterations.

\section{Materials and Methods}

Study design: This study is a cross sectional study. 
Place and duration of study: The study was carried in the laboratory of physiology at Faculty of Physical Education-Gezira Helwan University

\section{Study sample:}

Participants: This study presents data from long-distance running race. All athletes were trained for the longdistance running race, although the running experience varied from 1 to 5 years. Twelve runners participated in the study. They were asked not to perform any strenuous exercise or consume medication for 2 days before race. Each subject was his own control.

\section{Study methods}

Preliminary measurements: Maximal aerobic capacity (VO2max) was estimated using the Fox protocol (heart rate response to 5 min of cycle ergometry at $150 \mathrm{~W}$ $\left(6300-19.26^{\circ}-(\right.$ HR $5 \min )=$ VO2max $)$; (Fox 1973, Tirakitsoontorn et al., 2001).

Blood samples were collected via venipuncture 24 hours before (race) expected finish time (between 11:00 $\mathrm{AM}$ and 1:30 PM) to avoid circadian rhythm effects. The post race blood samples were collected at the finish site within 20 minutes at $0 \mathrm{~h}$ and 1 hour after completion of the race. During the race, runners drank ad libitum. Runners were asked to refrain from any training during a recovery period.

A complete blood count (CBC) was performed on EDTA-blood samples using an I-1800 Hematology Analyzer. Heparinized whole blood in 1:10 dilution was incubated with $5 \mathrm{mg} / \mathrm{ml}$ of phytohemagglutinin (PHA) from Phaseolus vulgaris, and $10 \mathrm{mg} / \mathrm{ml}$ of lipopolysaccharide (LPS) from E coli O26:B6 in RPMI-1640 supplement-ed with $2 \mathrm{ml}$ glutamine, $75 \mathrm{U} / \mathrm{ml}$ gentamicin sulfate for 24 hours at $37^{\circ} \mathrm{C}$ in a $95 \%$ humid atmosphere containing $5 \%$ of $\mathrm{CO} 2$. Supernatants were collected, and levels of IL-10, and TNF- $\alpha$ were assayed with commercial EASIA kits (Medgenix Diagnostic distributed by INC- STAR, Stillwater, Minn) in all twelve runners. Additionally, secretion of IL-6 in PHA/LPS stimulated cultures as well as plasma levels were assessed in the twelve runners who participated in the race. Minimal detectable levels of EAS-IA kits were (IL-10 - 1 pg./ml, TNF- $\alpha$ - 3 pg./ml, and IL-6 - 2 pg./ml).

Serum or EDTA plasma samples 
were collected on ice and stored at $-70^{\circ} \mathrm{C}$ until assays were performed. Plasma levels of cortisol (CORT), ACTH, $\beta$-endorphin $(\beta E N-D O)$, growth hormone $\mathrm{GH}$ and creatine phosphokinase (CPK) were analyzed with commercial RIA and IRMA kits. Plasma volume shift due to raceinduced dehydration was calculated by the method of Dill and Costill 1974.

\section{Statistical Analysis}

One-way ANOVA was used to analyze interval-dependent differences. SigmaStat (SPSS Inc., Chicago, Ill) statistical software package was used to determine normality of variances and where parametric or nonparametric methods were appropriate. Pearson product moment correlation test and random-effects regression model were used to analyze possible relations between studied variables. A value of $\mathrm{P} \leq .05$ was considered statistically significant. Power of performed tests with alpha .05 for runners $(n=12)$ was equal to 1.000. All data are presented as mean \pm standard error of the mean (SEM) of its corresponding units except (Table 1), in which demographic and performance data are presented as mean \pm standard deviation (SD).

\section{Consent:}

Before the start of the study, subjects provided written informed consent.

\section{Ethical Approval:}

The protocol was approved by the Ethical committee of laboratory of Exercise Physiology at Faculty of Physical Education Gezira, Helwan University. 


\section{Result}

Table 1. Demographic and fitness data for runners who participated in the studies (mean \pm SD) Variable $(n=12)$

\begin{tabular}{|c|c|c|c|c|c|c|}
\hline \multicolumn{7}{|c|}{ Variable at Rest day } \\
\hline Age (years) & $\begin{array}{c}\text { Body height } \\
(\mathrm{cm})\end{array}$ & Body mass (kg) & $\begin{array}{c}\text { Training } \\
\text { (years) }\end{array}$ & Body fat $(\%)$ & $\begin{array}{c}\text { BMI } \\
(\mathrm{kg} / \mathrm{m} 2)\end{array}$ & $\begin{array}{c}\text { VO2max } \\
(\mathrm{ml} / \mathrm{kg} / \mathrm{min})\end{array}$ \\
\hline $13.51 \pm 1.29$ & $155.20 \pm 6.49$ & $50.70 \pm 3.41$ & $3.50 \pm 1.08$ & $12.3 \pm 3.6$ & $20.05 \pm 1.52$ & $41.2 \pm 5.72$ \\
\hline
\end{tabular}

Table (1) showed mean and SD for demographic and fitness data for children runners who participated in the long-distance running race. There is non-significant differences in all variables of demographic and fitness.

Table 2. Morphologic and hematologic changes in whole blood of runners

\begin{tabular}{|c|c|c|c|c|c|}
\hline \multirow{2}{*}{$\begin{array}{c}\text { Study } \\
\text { Intervals }\end{array}$} & \multicolumn{5}{|c|}{ Complete Blood Count $(103 \mathrm{cells} / \mu \mathrm{l})$} \\
\cline { 2 - 6 } & Granulocytes & Lymphocytes & MID-cells & Hemoglobin $(\mathrm{g} / \mathrm{dl})$ & Hematocrit(\%) \\
\hline Pre & $5.7 \pm 0.5$ & $2.5 \pm 0.3$ & $0.5 \pm 0.1$ & $14.5 \pm 0.6$ & $42.1 \pm 1.7$ \\
\hline Oh & $17.9 \pm 1.3^{*}$ & $2.4 \pm 0.2$ & $1.2 \pm 0.1^{*}$ & $15.4 \pm 0.2$ & $45.0 \pm 0.5$ \\
\hline $1 \mathrm{~h}$ & $15.7 \pm 0.8^{*}$ & $1.7 \pm 0.1^{*}$ & $0.8 \pm 0.1$ & $15.3 \pm 0.3$ & $44.1 \pm 0.6$ \\
\hline
\end{tabular}

*: Significant $(\mathrm{P} \leq .05)$

Table (2) showed a statistically significant increase in granulocyte and monocyte (MID-cell) counts with a significant decline in lymphocyte count were seen at $0 \mathrm{~h}$ and $1 \mathrm{~h}$. A significant increase in hemoglobin level was seen at the $0 \mathrm{~h}$ interval, with recovery by the next hour. Hematocrit increase, seen at $0 \mathrm{~h}$, was non-significant $(\mathrm{P}=$ .075) compared with Pre level. Data are presented as mean \pm SEM. 
Table 3. Cytokine Secretion in PHA/LPS Activated Cell Cultures

\begin{tabular}{|c|c|c|c|c|c|c|}
\hline $\begin{array}{c}\text { Study } \\
\text { Intervals }\end{array}$ & $\begin{array}{c}\mathrm{IL}-10 \\
(\mathrm{pg} . / \mathrm{ml})\end{array}$ & $\begin{array}{c}\mathrm{TNF}-\alpha \\
(\mathrm{pg} . / \mathrm{ml})\end{array}$ & $\begin{array}{c}\mathrm{IL}-1 \beta \\
(\mathrm{pg} . / \mathrm{ml})\end{array}$ & $\begin{array}{c}\text { IL-6 } \\
(\mathrm{pg} . / \mathrm{ml})\end{array}$ & IL-2 (IU/ml) & $\begin{array}{c}\text { IFN- } \gamma \\
(\mathrm{IU} / \mathrm{ml})\end{array}$ \\
\hline Pre & $445.3 \pm 69.3$ & $16937 \pm 1800.8$ & $4377.1 \pm 664.5$ & $16571.4 \pm 2058.1$ & $6.0 \pm 1.5$ & $210.8 \pm 26.6$ \\
\hline 0h & $310.0 \pm 44.3$ & $9594 \pm 1421.5^{*}$ & $2937.1 \pm 696.8$ & $13585.7 \pm 3105.4$ & $2.0 \pm 0.4^{*}$ & $17.7 \pm 3.5^{*}$ \\
\hline $1 \mathrm{~h}$ & $463.7 \pm 146.9$ & $11394 \pm 1522.8^{*}$ & $3162.9 \pm 617.1$ & $16200.0 \pm 1940.2$ & $1.6 \pm 0.2^{*}$ & $14.4 \pm 3.3^{*}$ \\
\hline
\end{tabular}

*: Significant $(\mathrm{P} \leq .05)$

Table (3) showed data are presented as mean \pm SEM. A near significant $(\mathrm{P}=$ .052) decline in IL-10 secretion (13\% decrease) was seen immediately (0h) after completion of the race. Mitogen-activated secretion of TNF- $\alpha$ significantly declined immediately after the race. A significant decline in the mitogen-activated secretion of IL- $1 \beta$ was observed at the $1 \mathrm{~h}$ interval.

Table 4. Correlation between immune responses cytokine secretion

\begin{tabular}{|c|c|c|}
\hline Variables & $\mathrm{IL}-10(\mathrm{pg} . / \mathrm{ml})$ & $\mathrm{IL}-1 \beta(\mathrm{pg} . / \mathrm{ml})$ \\
\hline $\mathrm{TNF}-\alpha(\mathrm{pg} . / \mathrm{ml})$ & $0.67 *$ & $0.556^{*}$ \\
\hline $\mathrm{IL}-6(\mathrm{pg} . / \mathrm{ml})$ & $0.56^{*}$ & $0.553 *$ \\
\hline
\end{tabular}

*: Significant $(\mathrm{P} \leq .05)$

Table (4) showed highly significant correlations analysis of cytokine IL-10 to TNF- $\alpha$ and IL-6 ( $r=0.67$ and $r=0.56$, correspondingly), Conversely, TNF- $\alpha$ correlated with IL-1 $\beta(r=.556)$. Significant IL-1 $\beta$ and IL-6 $(r=.553)$. 
Table 5. Correlation between neuroendocrine and humoral responses

\begin{tabular}{|c|c|c|}
\hline Variable & ACTH & Cortisol \\
\hline$\beta$-endorphin & $0.816^{*}$ & $0.81^{*}$ \\
\hline Cortisol & $.604^{*}$ & \\
\hline
\end{tabular}

*: Significant $(\mathrm{P} \leq .05)$

Table (5) showed highly significant correlations were observed for ACTH versus $\beta$-endorphin $(\mathrm{r}=.816)$, ACTH versus cortisol $(\mathrm{r}=.604)$, and cortisol versus $\beta$-endorphin ( $\mathrm{r}=.81$ ) plasma levels, which reflect systemic HPA axis response to stress. These results represent a "classic" stress response.

Table 6. Correlation between HPA axis hormones (in vivo activity) on immune responsiveness in vitro.

\begin{tabular}{|c|c|c|c|c|c|c|c|c|c|c|c|c|}
\hline \multirow[t]{2}{*}{$\begin{array}{c}\text { Study } \\
\text { Intervals }\end{array}$} & \multicolumn{2}{|c|}{$\begin{array}{c}\text { IL-10 } \\
\text { (pg./ml) }\end{array}$} & \multicolumn{2}{|c|}{$\begin{array}{l}\text { TNF- } \alpha \\
\text { (pg./ml) }\end{array}$} & \multicolumn{2}{|c|}{$\begin{array}{c}\mathrm{IL}-1 \beta \\
(\mathrm{pg} . / \mathrm{ml})\end{array}$} & \multicolumn{2}{|c|}{$\begin{array}{c}\mathrm{IL}-6 \\
\text { (pg./ml) }\end{array}$} & \multicolumn{2}{|c|}{$\begin{array}{c}\mathrm{IL}-2 \\
(\mathrm{IU} / \mathrm{ml})\end{array}$} & \multicolumn{2}{|c|}{$\begin{array}{l}\mathrm{IFN}-\gamma \\
(\mathrm{IU} / \mathrm{ml})\end{array}$} \\
\hline & $\mathrm{r}$ & $\mathrm{p}$ & $\mathrm{r}$ & $\mathrm{p}$ & $\mathrm{r}$ & $\mathrm{p}$ & $\mathrm{r}$ & $\mathrm{p}$ & $\mathrm{r}$ & $\mathrm{p}$ & $\mathrm{r}$ & $\mathrm{p}$ \\
\hline Cortisol & 0.10 & 0.3 & 0.03 & $0.002^{*}$ & 0.10 & 0.5 & 0.16 & 0.3 & 0.63 & $0.001 *$ & 0.82 & $0.001 *$ \\
\hline
\end{tabular}

*: Significant $(\mathrm{P} \leq .05)$

Table (6) showed correlative analysis between HPA axis hormones (in vivo activity) on immune responsiveness in vitro. Correlations were observed for IL-10 insignificantly to cortisol $(r=0.10, p=0.3), T N F-\alpha(r=0.03 \mathrm{p}=0.002)$ significantly correlated to cortisol, IL-1 $\beta(\mathrm{r}=0.10 \mathrm{p}=0.5)$ insignificantly to cortisol, IL-6 ( $\mathrm{r}=$ $0.16 \mathrm{p}=0.3)$ insignificantly to cortisol, IL-2 $(\mathrm{r}=0.63 \mathrm{p}=0.001)$ significantly to cortisol, IFN- $\gamma(\mathrm{r}=0.82 \mathrm{p}=0.001)$ significantly to cortisol. A similar pattern was seen for $\beta$-endorphin and ACTH. 


\section{Discussion}

A Long-distance running race is a stressful event that comprises of a variety of physical as well as physiologic cognitive and non cognitive factors, and it is often associated with immuno suppression (Parryet al., 1992, Peters et al., 1997, Bouic et al., 1999, Suzuki et al., 2000). Several earlier epidemiologic studies showed increased risk of URTI in athletes up to 2 weeks after participation in marathon running or Long-Distance Running (Nieman et al. 1990, Peters et al., 1997). Despite a large number of publications on the issue, the variety of employed methods, lack of homogeneity in the population sample (gender, running experience), and the effect of environmental factors (climate, humidity, altitude) make the comparative analysis difficult. Our data indicate that prolonged and intensive endurance running race produces significant alterations in the distribution of leucocytes (Table 2), affects immune and neuroendocrine homeostasis (Table 4), and leads to skeletal muscle damage (Table 5) in subjects with wide experience. The majority of changes were seen immediately after prolonged running completion (Appell et al., 1992). In most of the studies pertaining to prolonged exhaustive exercise, data collection and analysis of recovery were limited to a few days. In the present study we attempted to evaluate the immune and neuroendocrine response to prolonged running throughout extended recovery period. Additionally, we analyzed correlative relations between studied variables to reveal potential immune and neuroendocrine interactions.

The present study uses both in vitro (cell cultures) and in vivo (plasma) immunologic models and evaluates the neuroendocrine response to stress to understand the underlying physiologic mechanisms of observed changes. We used a mixture of PHA and LPS as a nonspecific activator for cytokine secretion in cell culture (De Groote et al., 1993, Benyoucef et al., 1997). LPS is a very potent, physiologically relevant activator of monocytes and can be used to optimally stimulate cytokine production in cell cultures. It has been shown that combination of PHA and LPS gives the most reliable production of IL-1 $\beta$, IL-6, TNF- $\alpha$, and GM-CSF 
compared with production of these cytokines after activation with either PHA or LPS alone (De Groote et al., 1992). However, the use of this stimulus makes the identification of source cells for a number of cytokines difficult. For example, although IL-10 is produced by lymphocytes after PHA activation, it can also be secreted by monocytes in response to LPS challenge

The observed diverse results in the PHA/LPS activated secretion of IL-2 and IFN- $\gamma$ on the one hand, and IL-10 and IL- 6 on the other hand, suggest a shift in the cell-mediated or humoral immune balance, as assessed in the vitro model. These findings correspond very well to the current model of stress induced immune changes, in which corticosteroids play a significant role (Blotta et al., 1997, Besedovsky et al., 2000). Additionally, down regulated secretion of IL- 2 and IFN- $\gamma$ can be explained by three nonexclusive mechanisms. First, it can be related to the lymphopenia seen in our and other studies (Suzuki et al., 1995), and especially by the reported decrease in the number of the major producers of these cytokines ( $\mathrm{T}$ - and NK-cells) after a prolonged running race (Haq et al., 1993, Nieman et al., 1995, Castell et al., 1997). Second, elevation in the number of target cells (granulocytes, monocytes) may play a significant role in the observed decrease of cytokine secretion. The third possible mechanism is a decrease in the percentages of IL-2 and IFN- $\gamma$ secreting CD4+ and CD8+ T-cells registered after a 2.5-hour run in the study of Steensberg et al (2001). One of the explanations of this phenomenon is that dramatic elevation of HPA axis stress hormones may significantly affect functional properties of immune cells in vivo. Also, because we used whole blood culture, the presence of high concentrations of stress mediators in the culture could be responsible for in vitro changes.

One of the study objectives was to correlate in vitro and in vivo immune responses; therefore we used a whole blood cell culture (WBC). It appears that WBC represents the closest and maybe the most appropriate in vitro model to study immune re-actions because it preserves cellular and humoral in vivo milieu. However, in this study, in vitro immune response registered 
in the cell culture did not reflect changes seen in plasma cytokine (in vivo) concentrations. On one hand, we observed elevation in MID-cell count and an increase in plasma concentration of IL- 6 and TNF- $\alpha$ and this observation is supported by the literature (Castell et al., 1997, Ostrowski et al., 2000, Nieman et al., 2001). Conversely, a significant decrease in the secretion of these cytokines was registered in mitogen-stimulated cell culture at the same intervals. The revealed opposed pattern of IL-6, and TNF- $\alpha$ secretion in cell culture and their plasma levels suggests that not only immune cells are involved in the post-prolonged running race immune changes (high level of plasma IL-6 can be tissue originated). This observation is supported by the literature data (Ostrowski et al., 1998, Starkie et al., 2001). These findings suggest that these changes are not leukocyte dependent and that prolonged running race-associated stress factors significantly alter functional properties of immunocytes and other cytokinesecreting cells.

Analysis of activated cytokine ratios suggests a shift in cytokine equilibrium.
Assuming that IL-2/IL-10 ratio reflects type-0/type-2, IL-2/IFN $\gamma$ ratio to type$0 /$ type- 1 , and IFN- $\gamma / \mathrm{IL}-10$ ratio to type-1/type- 2 balances, it appears that prolonged running race favors the type2 immune response. The fact that these alterations were registered immediately after marathon suggests the involvement of neuroendocrine stress mediators (especially HPA axis), (Visser J. Et al., 1998) which are predominantly released during this race. This data corresponds to the current concept of neuroendocrine regulation of immune stress-response and is supported by the literature. The emotion-al component of prolonged running race and psychological profile of runners should not be omitted while discussing the results. A pre-marathon raise in saliva cortisol and testosterone levels has been documented (Cook et al., 1989, Scavo et al., 1991).

Correlative analysis revealed a number of high and significant interrelations between immune and endocrine parameters, which were primary driven by time effect plasma ACTH level significantly and negatively correlated with in vitro secretion of IL-2 and IFN- $\gamma(r=-0.53$ 
and $r=-0.536$, respectively). Analogous interactions were seen for $\beta$-endorphin. No other correlative interactions were found for these hormones and cytokines secretion. A significant but low correlation was observed between IL-2 secretion and plasma level of growth hormone $(r=-0.4)$. Observed changes in the plasma ACTH, $\beta$-endorphin, and cortisol levels reflect the classic stressinduced neuroendocrine response and correspond to the results from other studies (Scavo et al., 1991, Heitkamp et al., 1996). Similarly, our results on increase in plasma growth hormone level are consistent with data of Scavo (Scavo et al., 1991) and Suzuki (Suzuki et al., 2000). These results suggest that the HPA response (plasma ACTH, $\beta$-endorphin, and cortisol) affects mostly secretion of lymphocytes- derived but not monocyte- derived cytokines.

\section{Conclusion}

The current model of stress response is becoming further complicated. It involves both inter-and intrasystemic interactions in practically all physiologic bodily systems. Close interactions between neuroendocrine and immune systems are well documented, and their homeostatic balance is critically important for development of the appropriate immune response. Our data supports the current model of stress-induced neuroendocrine immunomodulation and shows that stress factors of long running alter the immune response by shifting the cytokine balance. It appears that prolonged running race-associated stress factors predominantly affect type1 immunity, and, to a lesser degree, type-0 and type- 2 immune responses.

Down-regulation of type-0 and type-1 cytokine secretion pre-signifies a decrease in the secretion of type- 2 cytokine. Stress-induced modulation of cytokines is primary mediated by the HPA axis and the secretion of type- 0 and type-1 cytokines are mainly affected. Alterations in the secretion of proinflammatory and anti-inflammatory cytokines can be registered immediately at finish line and can be detectable. This information may be beneficial for the development of new counter measures to preserve the wellness of athletes and subjects undergoing extensive physical stress. 


\section{Conflict of interest:}

Authors have declared that no conflict of interests exists.

\section{Acknowledgments}

We would like to thank all staff of the Laboratory of physiology at Faculty of Physical Educati on-Gezira Helwan University for their help in data collection and all athletes participated in these studies.

\section{References}

1. Appell HJ, Soares JM and Duarte JA (1992): Exercise, muscle damage and fatigue. Sports Med; 13:108-115.

2. Banfi G, Marinelli M and Bonini P, et al. (1996): Pepsinogens and gastrointestinal symptoms in mountain marathon runners. Int J Sports Med; 17:554-558.

3. Baril L, Caumes E, and Bricaire F (1998): Pubic pain after a marathon. Lancet; 351:642.

4. Bauer ME, Vedhara K, Perks P, et al. (2000): Chronic stress in caregivers of dementia patients is associated with reduced lymphocyte sensitivity to glucocorticoids. J Neuroimmunol; 103:84- 92 .

5. Baum M, Muller-Steinhardt M, Liesen $\mathrm{H}$ and Kirchner H (1997): Moderate and exhaustive endurance exercise influences the interferongamma levels in whole-blood culture supernatants. Eur J Appl Physiol Occup Physiol; 76:165-169.

6. Benyoucef S, Hober D, Shen L, et al. (1997): Production of TNF alpha and IL- 6 by activated whole blood from HIV-1 infected patients detected by a one- stage procedure: relationship with the phenotype of HIV-1 isolates. Microbiol Immunol; 41:939-946.
7. Besedovsky HO and del Rey A (2000): The cytokine-HPA axis feed-back circuit. Z Rheumatol; 59(2):26-30.

8. Blotta MH, DeKruyff RH and Umetsu DT (1997): Corticosteroids inhibit IL-12 production in human monocytes and enhance their capacity to induce IL-4 synthesis in CD4+ lymphocytes. J Immunol; 158:5589-5595.

9. Bouic PJ, Clark A, Lamprecht J, et al. (1999): The effects of B-sitosterol (BSS) and B-sitosterol glucoside (BSSG) mixture on selected immune parameters of marathon runners: inhibition of post marathon immune suppression and inflammation. Int J Sports Med; 20:258-262.

10. Castell LM, Poortmans JR, Leclercq R, et al. (1997): Some aspects of the acute phase response after a marathon race, and the effects of glutamine sup- plementation. Eur J Appl Physiol Occup Physiol; 75:47-53.

11. Cook NJ, Read GF, Walker RF, et al. (1986): Changes in adrenal and testicular activity monitored by salivary sampling in males throughout marathon runs. Eur J Appl Physiol Occup Physiol; 55:634-638.

12. Daynes RA and Araneo BA (1989): Contrasting effects of glucocorticoids on the capacity of $\mathrm{T}$ cells to pro- duce the growth factors interleukin 2 and inter- leukin 4. Eur J Immunol; 19: 23192325 .

13. De Groote D, Gevaert Y, Lopez M, et al. (1993): Novel method for the measurement of cytokine production by a one-stage procedure. J Immunol Methods; 163:259-267.

14. De Groote D, Zangerle PF, Gevaert Y, et al. (1992): Direct stimulation of cytokines (IL-1 beta, TNF- alpha, IL-6, IL-2, IFN- gamma and GM$\mathrm{CSF}$ ) in whole blood. I. Comparison with isolated PBMC stimulation. Cytokine; 4: 239-248.

15. Dill DB and Costill DL (1974): Calculation of percentage changes in volumes of blood, plasma, and red cells in dehydration. J Appl Physiol; 37:247-248. 
16. Drenth JP, Van Uum SH, Van Deuren M, et al. (1995): Endurance run increases circulating IL-6 and IL-1ra but down regulates ex vivo TNF-alpha and IL- 1 beta production. J Appl Physiol; 79:1497-1503.

17. Fox EL (1973): A simple, accurate technique for predicting maximal aerobic power. J Appl Physiol; 35: 914-916.

18. Haq A, Al-Hussein K, Lee J, Al-Sedairy S (1993): Changes in peripheral blood lymphocyte subsets associated with marathon running. Med Sci Sports Exerc; 25:186-190.

19. Heitkamp HC, Huber W and Scheib K (1996): Beta- Endorphin and adrenocorticotrophin after incremental exercise and marathon runningfemale responses. Eur J Appl Physiol Occup Physiol; 72:417-424.

20. Laurel TM (1999): Advances in exercise immunology. United States: Human Kinetics. Champaign, IL . Copright (C) .

21. Molijn GJ, Spek JJ, van Uffelen JC, et al. (1995): Differential adaptation of glucocorticoid sensitivity of peripheral blood mononuclear leukocytes in patients with sepsis or septic shock. J Clin Endocrinol Metab; 10:1799-1803.

22. Nieman DC, Henson DA, Fagoaga OR, et al. (2002): Change in salivary IgA following a competitive marathon race. Int J Sports Med; 23:69-75.

23. Nieman DC, Henson DA, Smith LL, et al. (2001): Cytokine changes after a marathon race. J Appl Physiol; 91:109-114.

24. Nieman DC, Nehlsen-Cannarella SL, Markoff PA, et al. (1990): The effects of moderate exercise training on natural killer cells and acute upper respiratory tract infections. Int J Sp-orts Med; 11:467-473.

25. Nieman DC, Simandle S, Henson DA, et al. (1995): Lymphocyte proliferative response to 2.5 hours of running. Int J Sports Med; 16:404409.
26. O'Connor AM, Johnston CF, Buchanan KD, et al. (1995): Circulating gastrointestinal hormone changes in marathon running. Int J Sports Med; 16:283-287.

27. Ostrowski K, Rohde T, Zacho M, et al. (1998): Evidence that interleukin-6 is produced in human skeletal muscle during prolonged running. J Physiol; 508:949-953.

28. Ostrowski K, Schjerling $P$ and Pedersen BK (2000): Physical activity and plasma interleukin-6 in humans: Effect of intensity of exercise. Eur J Appl Physiol; 83:512-515.

29. Parry-Billings M, Budgett R, Koutedakis Y, et al. (1992): Plasma amino acid concentrations in the over- training syndrome: possible effects on the immune system. Med Sci Sports Exerc; 24:1353-1358.

30. Peters EM: (1997): Exercise, immunology and upper respiratory tract infections. Int J Sports Med; 18 (1); S69-77.

31. Scavo D, Barletta C, Vagiri D and Letizia C (1991): Adrenocorticotropic hormone, betaendorphin, cortisol, growth hormone and prolactin circulating levels in nineteen athletes before and after half-marathon and marathon. J Sports Med Phys Fitness; 31:401-406.

32. Starkie RL, Rolland J, Angus DJ, et al. (2001): Circulating monocytes are not the source of elevations in plasma IL-6 and TNF-alpha levels after prolonged running. Am J Physiol Cell Physiol; 280:C769-774

33. Steensberg A, Toft AD, Bruunsgaard H, et al. (2001): Strenuous exercise decreases the percentage of Type-1 $\mathrm{T}$ cells in the circulation. J Appl Physiol; 91:1708-1712.

34. Suzuki K, Naganuma S, Mochizuki M, et al. (1995): Differential patterns of the number and proportion of blood leukocytes following endurance exercise of moderate, strenuous and severe conditions. Nippon Eiseigaku Zasshi; 50:631-636. 
35. Suzuki K, Nakaji S, Yamada M, et al. (2003): Impact of a competitive marathon race on systemic cytokine and neutrophil responses. Med Sci Sports Exerc; 35:348-355.

36. Suzuki K, Yamada M, Kurakake S, et al. (2000): Circulating cytokines and hormones with immunosuppressive but neutrophilpriming potentials rise after endurance exercise in humans. Eur J Appl Physiol; 81:281-287.

37. Tirakitsoontorn P, Nussbaum E, Moser C, Hill M and Cooper DM (2001). Fitness, acute exercise, and anabolic and catabolic mediators in cystic fibrosis. Am J Respir Crit Care Med; 164: 1432-1437.

38. Viru A and Viru M (2004): Cortisol-essential adaptation hormone in exercise. Int $\mathrm{J}$ Sports Med; 25(6):461-464.

39. Visser J, van Boxel-Dezaire A, Methorst D, et al. (1998): Differential regulation of interleukin-10 (IL-10) and IL-12 by glucocorticoids in vitro. Blood; 91:4255-4264.

40. Weinstock C, Konig D, Harnischmacher R, et al. (1997): Effect of exhaustive exercise stress on the cytokine response. Med Sci Sports Exerc; 29:345-354. 